\title{
An Evaluation of Educational Music in Turkey Based on Composers' Opinions
}

\author{
Hatice Celiktas ${ }^{1} \&$ Sezen Ozeke ${ }^{1}$ \\ ${ }^{1}$ Music Education Department, Bursa Uludag University, Bursa, Turkey \\ Correspondence: Hatice Celiktas, Music Education Department, Bursa Uludag University, Bursa. E-mail: \\ haticeliktas@gmail.com
}

Received: July 16, 2019

Accepted: August 5, 2019 Online Published: September 20, 2019

doi:10.5539/jel.v8n5p106

URL: https://doi.org/10.5539/jel.v8n5p106

\begin{abstract}
There are various studies concerning the present situation of the phenomenon of educational music, which dates back to the early years of the Republic i.e. which emerged 90 years ago, the problems in the area, and solutions to these problems as well as the concept of "educational music" which is used to define the songs that are part of music education. The objective of the present study is to evaluate the area of educational music based on composers' opinions, in other words, on the opinions of the creators of the subject music, and to determine the present situation of the area in the light of these evaluations. For these purposes, 7 composers, all of whom had contributed to educational music, were interviewed. The resultant data were analyzed under three themes by means of content analysis. The themes were the concept of educational music, educational music compositions and educational music composing. As a result, composers indicated that songs composed as educational music pieces should have a content that children can relate to. They also said that music teachers and prospective music teachers who had the ability to compose should engage in the composition of educational music. According to composers, in order for songs to be of good musical quality; easy and catchy melodies and lyrics, prosody, melodic sequence, harmonic structure and form components were important. Composers also expressed their opinions regarding "the points to be considered and the method to be followed in the process of composition", "essential skills and knowledge in addition to the ability to compose", and "types of music preferred in compositions". In addition to this research, further studies, which take opinions of music teachers, who are the appliers of educational music, and those of students, who are the receivers and consumers of educational music, into account, can be undertaken so as to be able to evaluate the area of educational music from different perspectives.
\end{abstract}

Keywords: educational music, educational music composing, music education

\section{Introduction}

A range of alternative terms such as educational music, didactic music, Turkish school music, school music, school songs, children's music, children's music repertoire, school music repertoire are commonly used both by the stakeholders in the field and music educators to define and classify the songs used in music education (Aksu, 2010). Although these terms refer more or less to the same phenomenon, they vary in terms of scope and area of use. For example, Sun (1969) named the concept as Turkish school music by also referring to Turkish school songs, which belong to our culture and in his opinion, should be included in the field. Elmas, on the other hand, used the term didactic music and defined the concept as songs that ensure continuity in terms of the main principles of music education, educational values and elements that have a positive impact on singing (Aksu, 2010). Aksu (2010) used the term pedagogical music to define all pieces of music used as an auxiliary tool in the course of teaching activities not only in the area of music education but also in other disciplines; however, he preferred the term educational music for the phenomenon and provided the following definition:

Educational music is a set of musical tools that helps individuals acquire the fundamental and specific attainments in the discipline of music (basic knowledge on music such as notes, rhythm, solfege, playing instruments, music culture; and the specific attainments in professional music education); that aids the teaching of disciplines other than music (grammar, mathematics, social sciences, arts etc.); that is organized in a way that it can play an active role in building the desired motivation and connotations in any given class; that is designed in a way to respond to demands in all grades from the lowest to the top (preschool, 
elementary and middle school, high school and professional higher education); that comprises all kinds of music (Traditional Turkish Music genres, classical music genres, various genres of popular music and a range of world music genres); that has the potential to cover a broad range of topics and that can, apart from formal education, be used in non-formal education for people of all ages.

Aksu's definition of the term encompasses all alternative definitions entailed by terms such as Turkish school music, school music, didactic music, pedagogical music, children's music and children's music repertoire; and hence emerges as a concept that surpasses all of these definitions. For this reason, the term "educational music" is used when referring to this phenomenon in the present study.

Educational music has a history of over 90 years, which covers the period beginning from the republican era to date. Throughout this time, a variety of corporate projects and studies have been undertaken; a wide range of essays, articles, declarations, books and newspaper columns concerning educational music have been published. Besides, the volume and pace of such studies have increased particularly with the implementation of new post-graduate studies in the area. All these resources in the literature which also provide an insight into the issue and support the present study are presented below:

In his research, Özeren (2006) dealt with the degenerated music culture in our country indicating also that unrefined examples of popular music have an adverse effect on children's language and musical development. He added that music education will and should play an effective role in changing this adverse effect. In his declaration, Özeren stated that in order to raise social music consciousness there is a need for a common song repertoire. According to him, for the same purpose, music education at schools should build a taste and consciousness of music in students. Besides, events should be organized to increase the number of children's songs, mass communication tools should prefer the musically right pieces, all institutions should have awareness of school songs and finally, school songs should not be underestimated.

In a study Yıldız (2005) analyzed the songs that got the first place in the "Popüler Çocuk Şarkıları Yarışması" [Popular Children's Song Competition] organized by TRT between 1993 and 2004 in terms of their lyrics, music and prosodic features. He also examined the songs in terms of their tonality, scale, form and cognitive levels and in doing so, aimed to contribute to children's songs to be composed in the future.

In his study, Satır (2009) aimed to analyze songs for children in terms of language and expression by taking into consideration such aspects as students' conceptual-cognitive development levels and principles of modern children's literature. In the study, 21 songs from music course books for 1st, 2nd and 3rd grades were chosen as the sample. As a consequence, 7 of these 21 songs were found to lack the above-mentioned qualities. 4 songs were appropriate for the conceptual-cognitive levels of children; however, they did not have a semantic universe particular to children's world. It was emphasized that songs which are appropriate for linguistic-conceptual as well as cognitive levels of children should be preferred and during the process of composition verbal aspects should be given equal importance with the musical structure.

In their study, Gül and Bozkaya (2010) analyzed Üngör's "Çocuklara Teganni Dersleri” book in terms of its scope and quality and evaluated the book in terms of its effects on similar books published in the following years.

In his declaration, Sağer (2004) "Okul Şarkılarının Konuları Açısından Değerlendirilmesi" addressed the types of music used for music education at schools and classified all the songs in course books from the establishment of the Republic to 2004 in terms of their subjects. As a result, Sağer identified the names of those who contributed to children's music, music course books and music education the most; total number of songs in course books, the number of song writers and the number of school songs of Turkish folk music origin. He also found out that if the subjects of the songs were put in an order; patriotism emerged as the most frequent subject, which was followed by songs on love, pieces from Turkish folk music and finally, by songs about the New Year and animals.

In the literature review process; books, articles and declarations as well the postgraduate studies on music education in Turkey were explored and it was concluded that there was a bulk of studies in the area. The subject studies were accessed via the website of the National Thesis Center. "Educational music", "school music", "school songs" and "song" were used as keywords when browsing through the website.

In his doctoral thesis, Sağer (2002) investigated practices and developments in the area of educational music composition between the establishment of the Republic and 2002. For these purposes, music course books written between 1925 and 2002 in addition to 30 composers of educational music and these composers' contribution to educational music were explored. The thesis is a significant resource in that it is a historical study 
in the area and is broad in scope.

In several theses, accompaniment of school songs has been explored. Görsev's (2006) master's thesis investigated the relationship between ability to perform accompaniment to school songs and "Piano", "Musical Hearing, Writing and Reading" as well as "Theory of Music" courses in music education programs. In their master's theses, Akbulut (2001), Kaptan (2001), Parıldar (2006), Kutluk (1996), Yılmaz (2010) and Yungul (2008) examined accompaniment of school songs with the guitar; Kalkanoğlu (2007) and Özkeleş (2011) studied accompaniment of school songs with the piano and proposed solutions for the problems in the area.

In some master's and doctoral theses, on the other hand, the role of Turkish music in educational music has been discussed. Sağer (1998) focused on the role of the maqam system of Turkish art music in educational music while Özdemir (1998) addressed the usability of the music mode of Turkish folk music in educational music. In addition, Bağçeci (1996) wrote a thesis on the polyphony of educational music songs of modal style.

In Gül's (2012) doctoral thesis and Mohan's (2008) master's thesis, educational music in preschool settings was analyzed. Gül investigated what effects of the repertoire had on children's musical development while Mohan explored the opinions of teachers regarding the preschool songs about special days and weeks.

In several master's theses, educational music within the context of elementary \& middle school education has been researched. In her study, Sak (1997) referred to the importance of songs used in elementary \& middle education while Özeren (2001) compiled a song repertoire that was classified by topic and would be used in elementary \& middle education. Kalaycığlu (2009) analyzed 210 songs from the music books used as course books in Turkey during the academic year 2008-2009 against a range of criteria and evaluated the usability of these songs as school songs and their fitness for purpose. Bilgin (2009) explored elementary \& middle school students' opinions about school songs and Özelma (2010) studied polyphonic songs used in elementary \& middle school settings. Nebi (2005) conducted a comparative study on elementary \& middle school songs used in Turkey and the Former Yugoslav Republic of Macedonia. Çavuşoğlu (2006), Koz (2007), Aktaş (2008) and Güler (2009) investigated, in their master's theses, the facts and problems about middle school songs and proposed solutions for the subject problems.

In their master's theses, Tamer (2004) and Yağışan (1995) focused on the subject of educational music in high school settings. Tamer discussed the problems occurring due to the use of the song repertoire for 9th grades and tested an alternative song repertoire within the scope of her study. Yağışan, on the other hand, addressed the educational music issue in high school settings and analyzed two high school course books that were written in accordance with the music curricula of 1971 and 1986.

In Semiz's (2010) master's thesis and Arapgirlioğlu's (2003) doctoral thesis, the relationship between technology use and school songs was discussed. Selamet's (2009) master's thesis examined the use of songs composed for TRT's popular children's songs in elementary \& middle education. Furthermore, Dinç's (2011) master's thesis on Kazım Karabekir's contribution to educational music and Halvaşi's (1999) doctoral thesis on the role of the Turkish language in the formation of a national singing tradition are other significant examples from the relevant literature.

When the studies in the literature were reviewed, it was concluded that particularly postgraduate theses focused on and evaluated the general overview of the educational music as well as problems, compositions and composing in the area and that such studies also came to the conclusion that there were many problems in the area. In spite of this fact, it was noted that opinions of composers, who had shaped educational music, had not been addressed in any study. On the strength of this, within the scope of the present study, educational music composers were interviewed and the present situation of educational music was evaluated in the light of the composers' responses. The objective of the study was to make a rigorous evaluation of the area in relation to the concept of educational music, educational music compositions and educational music composing in the light of the content from the interviews conducted with educational music composers.

\section{Method}

\subsection{Research Model}

"Case study" method, a descriptive research model, was employed for the study purposes. Case study is an empirical research model used to define and explain a given case in detail and to study a present-day phenomenon in its real-life context. It is also adopted when the boundary between a given fact and its context is vague and there is more than one evidence or data source (Çepni, 2010; Yin cited in Yıldırım \& Şimşek, 2011). In accordance with the above-given definition of the model, in this study, educational music composers were asked questions about all aspects of educational music and a "case study" was conducted in order to reveal the 
current situation of educational music.

\subsection{Study Group}

All the educational music composers who are alive today constitute the target population. The study population, on the other hand, was selected in accordance with stratified purposeful method. Stratified sampling method is divided into two groups as stratified random sampling and stratified purposeful sampling. In stratified random sampling could be maked generalizations and statistically valid comparisons by social class as well as to generalize to the total population. But, in stratified purpose sampling has too small size from stratified random sampling for generalization or statistical representiveness. The purpose of this sampling is to capture major variations rather than to identify a common core. In stratified puspose sampling, each of strata [subgroups] would constitute a fairly homogeneous sample (Patton, 2002). In the present study, 3 subgroups of composers, who were selected from among the target population, were formed in the light of the study data. Details of the subgroups are explained below:

- First Subgroup: Composers with a background in composition and with books on children's songs.

- Second Subgroup: Composers who provided the greatest contribution to educational music repertoire.

- Third Subgroup: Composers won prizes in TRT's children's songs competitions.

Composers in the first subgroup comprised those with books on children's songs who produced pieces of large music forms and also contributed to the area of educational music. The second subgroup consisted of composers with remarkable contribution to educational music repertoire. Information about the second subgroup composers was gathered from Sağer's (2002) doctoral thesis Cumhuriyet'ten Günümüze Okul Şarkıları Üzerine Bir İnceleme. Sağer, in a section of his study, provided a list of educational composers in an order of productivity i.e. in accordance with the number of music pieces added into the relevant repertoire. The composers in the list have been and still are academics teaching at departments of music education. The third subgroup involved the composers who composed for periodic children's songs competitions organized by TRT and were deemed worthy of an award. The competition was first held in 1990 and was staged in the following years, namely in 1993, 1995, 1998, 2000, 2002, 2004, 2007, 2009, 2011, 2013, and 2015 as well. Compositions and composers who won the first place between 1993 and 2007 were indicated in Selamet's (2009) master's thesis entitled TRT Popüler Çocuk Şarkılarının Okul Müzik Eğitiminde Kullanımı [Use of TRT’s Popular Children's Songs in Music Education]. Some composers would be placed in two subgroups; in such cases, the subject composers were placed in the subgroup in which they were more prolific. Composers, divided into three subgroups with each respondent assigned to only one subgroup, were encoded as Composer 1, Composer 2 etc. Their codes were determined randomly by drawing lots. As a consequence, a total of 7 composers were interviewed with Composer $1(\mathrm{C} 1)$ and Composer 7 (C7) representing the first subgroup; Composer 2 (C2), Composer 5 (C5) and Composer 6 (C6) from the second subgroup; Composer 3 (C3) and Composer 4 (C4) on behalf of the third subgroup (See Table 1). The fact that interviewed composers were leading figures in the development of educational music in Turkey and contributed to the area by means of their compositions raises the importance of the present study.

Table 1. The composers which subgroups represent

\begin{tabular}{lll}
\hline First subgroup & Second subgroup & Third subgroup \\
\hline C1 & C2 & C3 \\
C7 & C5 & C4 \\
& C6 & \\
\hline
\end{tabular}

\subsection{Data Collection Tool}

In the study, a literature review was conducted to gain an insight into the area and in the light of this review; "An Interview Form for Composers' Evaluation of the Area of Educational Music" was prepared to acquire information about educational music composers' opinions regarding educational music. With the help of two experts from the area, final versions of the interview questions were designed. Interview form was prepared with due consideration to all aspects of educational music and was divided into three sections. These were: the concept of educational music, educational music compositions and educational music composing.

\subsection{Collection and Analysis of the Data}

Data were obtained from the interviews conducted with the selected composers. The subject data were analyzed 
using content analysis, a method that aims to combine data sets within the framework of certain concepts and themes as well as to organize and interpret them in a way that is comprehensible by the readers" (Yıldirım \& Şimşek, 2011). In the interpretation of content analysis, it is possible to make a list of codes before gathering data when the research is based on a theory or a conceptual framework (Yıldırım \& Şimşek, 2011). In the present study, interview questions directed to composers were classified in accordance with the section headings and a code list for the content analysis was prepared before the analysis of the data (See Table 2).

Table 2. List of themes and codes

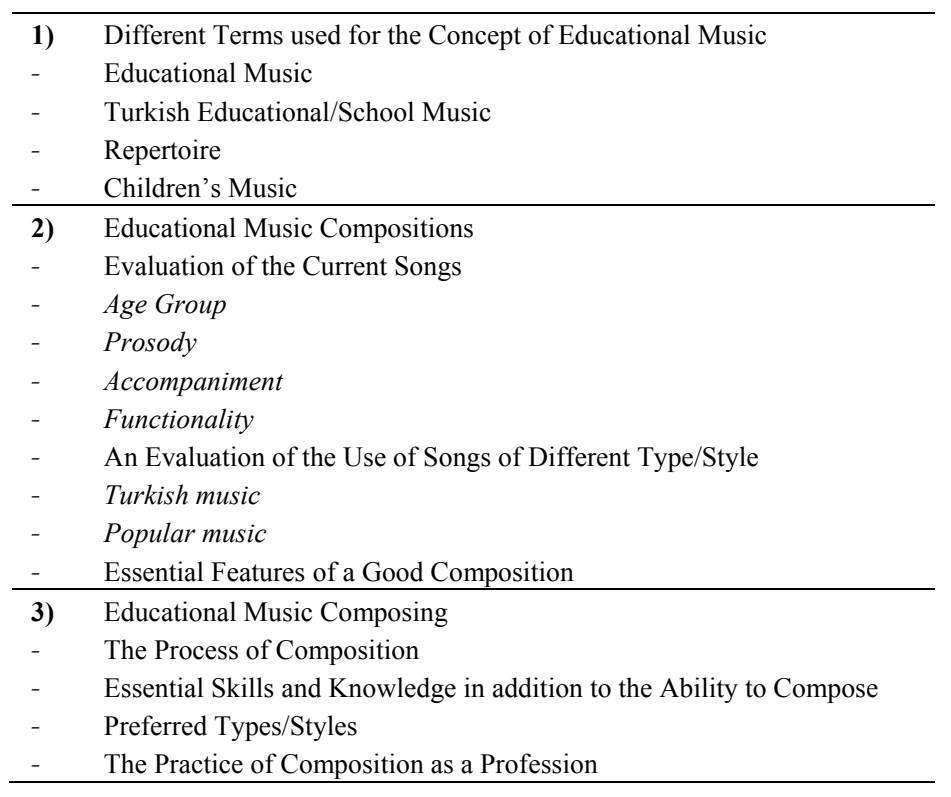

A total of 7 composers were interviewed during the research; 5 of them joined in face-to-face interviews while the other 2 were contacted via e-mail. In the analysis of the data, composers were encoded as C1, C2, C3 and so on and the data were presented under these codes.

\section{Results}

The headings in this section were designated on the basis of the list of themes and codes provided in Table 1 . Under each heading, main ideas from among the opinions of composers were compiled as bullet point statements and were presented in tables. In this way, it was aimed to build a more reader-friendly way of presentation and to show the similarities among the statements more clearly.

\subsection{Different Terms Used for the Concept of Educational Music}

As explained in the first section of the study, there are several terms used to refer to the concept of educational music. Composers were asked if all these terms were of the same meaning and which one of these terms they preferred using and the reasons for preferring one over another. As is the case in the relevant literature, it was recognized that composers also used the terms "educational music", "Turkish educational music", "Turkish school music", "children's music" and "repertoire". Among these terms, however, the term "educational music" was the most commonly used one (See Table 3).

Table 3. Terms used by composers to refer to the concept

\begin{tabular}{ll}
\hline Term & Composer \\
\hline Educational Music & $\mathrm{C} 1, \mathrm{C} 2, \mathrm{C} 5$ \\
Turkish School/Educational Music & $\mathrm{C} 6, \mathrm{C} 7$ \\
Repertoire & $\mathrm{C} 3$ \\
Children's Music & $\mathrm{C} 4$ \\
\hline
\end{tabular}




\subsubsection{Educational Music}

Composers who used the term "educational music" $(\mathrm{C} 1, \mathrm{C} 2, \mathrm{C} 5)$ evaluated the concept in relation to the materials used and indicated that they preferred the term "educational music" since it had a broader meaning. In their definitions, composers emphasized the diversity of the materials used in music education. Therefore, the concept of educational music was referred to as all the musical materials that are used in the realization of musical education at different levels and for different purposes.

\subsubsection{Turkish Educational/School Music}

Two composers combined the term with the word Turkish. Of them, composer encoded as C6 preferred "Turkish educational music" while the other composer (C7) used the term "Turkish school music". The composer using the term "Turkish school music" said that he evaluated the materials in terms of their cultural and national characteristics and divided them into four types as adaptations, emulations, folk songs and Turkish school songs. He believed that adding all these types together created Turkish school music.

\subsubsection{Repertoire}

Another composer (C3) indicated the term "repertoire" was employed to mean all the music pieces used in education and stated that the search for new terms stemmed from the inability to express opinions, actions or situations.

\subsubsection{Children's Music}

One of the composers (C4) suggested that educational music was a broad term and in order to refer to the phenomenon, he preferred the term "school songs" or "children's songs"; and according to this composer, the term "children's songs" was more appropriate than the others.

In conclusion, terms used to define the songs in the basic music education varied among the composers and it turned out that five distinct terms were used in the area (educational music, children's music, repertoire, Turkish school music, Turkish educational music). Due to the broader meaning and expressive power it entails, "educational music" was by far the most commonly used term among the composers. Due to the same reasons, "educational music" was considered more appropriate for the present study and it was used throughout the study.

\subsection{Educational Music Compositions}

In this theme which provided the opinions and evaluations concerning educational music compositions, the data were divided into three categories. These were: an evaluation of the current repertoire in relation to a variety of criteria, an evaluation of the use of educational music songs of different types/styles, and essential features of a good composition.

\subsubsection{Evaluation of the Current Songs}

Composers were requested to evaluate the current songs in relation to a range of criteria including age group, prosody, musicality, relevance to the time/up-to-dateness etc. In the light of their responses, the composers were found to be particularly sensitive about the age group, prosody, piano accompaniment of school songs and functionality of songs.

\subsubsection{Age group}

In the evaluation of the repertoire according to age groups, composers usually based their evaluations on grade levels. Composers considered the number of songs for the age groups in the elementary \& middle education sufficient while they were of the opinion that the repertoire was insufficient for preschool and high school groups (See Table 4).

Table 4. Composers' opinions concerning appropriateness and sufficiency of the repertoire in relation the age group criterion

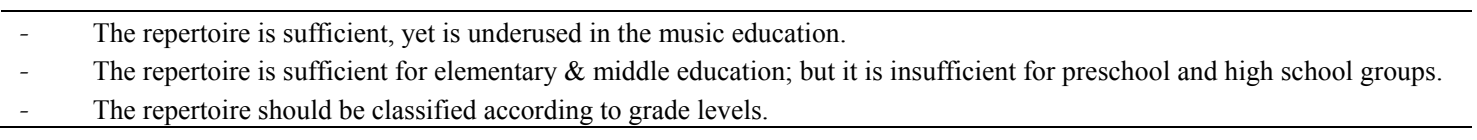

Composers $(\mathrm{C} 2, \mathrm{C} 4, \mathrm{C} 5)$ thought that the repertoire was sufficient for the elementary \& middle education while they were of the opinion that the repertoire was insufficient for preschool and should therefore be developed. Due to the inadequacy of the repertoire of preschool songs, preschool teachers sought alternative solutions to 
cover for it. Composers (C5) made up songs for the topic to be addressed in the classroom on a specific day just in order to save the day; however, they remarked that those songs were far from being long-lasting and would not appeal to the taste of other teachers. Composers expected authorities to release the current songs by means of advertisements and promotion so as to effectuate some improvement in the area. Another composer (C7) believed that the current repertoire was actually sufficient; however, most pieces in the repertoire were not covered in music education. C7 explained the reason for this with the lack of knowledge of a given teacher about the repertoire or lack of competence, again on the side of teachers, to use the repertoire in classroom settings. This composer also was of the opinion that weekly class hours in music education were not enough and this would be a factor in the underuse of/inability to use the songs in the repertoire.

Children/students at high school are in a new phase of life, according to one of the composers (C2), and therefore, their interest would be shifted to other subjects or music types. Composers stated that the demand for educational music for this age group was less than other educational groups; hence, fewer songs were composed for those in this group. They reported that, as a result of this, the number of songs for the subject age group remained low with insufficient content.

In another composer's opinion (C3), the current song repertoire should be classified in accordance with grade level and in doing so; the issue of age group should be handled in a sensitive and thoughtful way. Composers added that several competitions had been held up to that time and thanks to those competitions many songs had at once been included in the repertoire. Therefore, they argued this job should be assumed by some institutions and if the already existing books and CDs would be released, the current repertoire would be enhanced.

Considering composers' opinions, it can be concluded that the subject song repertoire is sufficient for elementary \& middle school age group although new songs need to be composed for preschool and high school grade levels. Besides, teachers should familiarize themselves with the current repertoire and use it in their classes.

\subsubsection{Prosody}

Composers $(\mathrm{C} 1, \mathrm{C} 3, \mathrm{C} 7)$ emphasized the significance of prosody; yet pointed out the large number of songs with prosodic errors. They added that, in spite of the errors, those songs were still in use as they were incorporated into the language. Composers $(\mathrm{C} 2, \mathrm{C} 4)$ stated that giving due attention to melody and integrating the lyrics into the music in a conversational style were necessary to create harmony between lyrics and music and to compose songs without prosodic errors. They believed that only if these conditions were satisfied, could songs become part of children's lives (See Table 5).

Table 5. Composers' opinions concerning the evaluation of the repertoire in terms of prosody

- Many songs with prosodic errors have been incorporated into the language and they are still in use.
- When composing songs, giving due attention to melody and integrating the lyrics into the music in a
conversational style are necessary.

As composers' opinions might also imply, the issue of prosody bears particular importance for compositions.

\subsubsection{Accompaniment}

One of the composers (C4) attached particular importance to the issue of accompaniment of songs and thought that the harmony of a song was the complementary element of a song and it was what made a song beautiful; therefore, songs should be composed in a way that they could be accompanied by the piano. He argued, however, several songs that were currently in use did not have piano accompaniment (See Table 6).

Table 6. Composers' opinions concerning piano accompaniment to songs

\footnotetext{
- Several songs were composed without piano accompaniment.

- Songs should be composed in a way that they can be accompanied by the piano.

- A good composer and a good music teacher should absolutely be good at playing the piano.
}

This composer responded that a good composer and a good music teacher should absolutely be good at playing the piano and songs should be composed in a way that they could be accompanied by the piano. Although this was not noted by other composers, it was considered to be worthy of attention as the composer put particular emphasis on this issue. Accordingly, this issue was addressed under this separate heading. 


\subsubsection{Functionality}

Composers were asked what place the songs to be used as course materials in music education should hold in children's lives and their contribution to children's daily lives should be like. For this purpose, they were expected to evaluate the current repertoire (See Table 7).

Table 7. Composers' opinions concerning the functionality of the songs

- Not all the songs learnt at school appeal to children. Only experts should compose music.
- Songs used in music education should definitely be integrated into children's daily lives.
- Songs composed for the sake of art have the potential to be used as course materials and at the same time can penetrate
in children's daily lives.
- Composing songs for educational purposes or for children requires particular effort.

When evaluating the current situation in the area, one composer (C1) expressed regrets on the fact that not every song learned at school could appeal to children or could leave its mark on children's lives. One composer (C5) who emphasized the necessity to take children's cognitive levels and similar aspects in the process of composition argued that if songs for music education were composed for the sake of art, they could have the potential to be used as course materials and at the same time could penetrate in children's daily lives. Composers who did not have concerns like "I compose it for a school, and hence it would be better this way" or "They will be used in daily life and thus I should compose them this way" during the process of composition (C4, C5, C6, C7) said they would have such concerns only when composing for special days or weeks. Some composers were of the opinion that if songs were composed for children, they should definitely be of a style that could penetrate in children's daily lives and only songs composed with this approach would be welcomed by children. Some (C3, C4) claimed that composing songs to be used in music education required particular effort and that a composer should be work diligently to achieve this. They also pointed out that songs which appealed to children should help children divert to the right path in their future lives and offer guidance to them.

All these opinions of composers suggest that songs composed for children or to be used for specific purposes can penetrate into children's lives in any form. Besides, their views demonstrate that songs of this style can be part of children's lives and teachers can use these songs as teaching aids in their classes.

\subsubsection{An Evaluation of the Use of Songs of Different Type/Style}

All of the respondent composers indicated that the portfolio in music education should be broad and provided that the music was good and of a high standard, all types of music should without exception be included in music education. Some composers who stated that the most important thing was to follow a planned and progressive approach (e.g., in the first place tonal songs, later on modal songs and songs with maqam, and finally examples from world music) claimed that all kinds of songs could be taught to children as long as they were composed for children or were appropriate for children.

\subsubsection{Turkish Music}

Tuning system of Turkish music with maqams (particularly traditional Turkish art music) differs from the tempered system. Besides, original pieces composed in the area are known to surpass the readiness levels of primary, middle and high school students. Due to this fact, composers' opinions regarding the use of traditional Turkish music pieces in music education were asked and they are presented in Table 8.

Table 8. Composers' opinions regarding the use of Turkish music pieces in music education

\footnotetext{
- Turkish music should be included in music education. Keeping it outside the scope of music education is not a realistic approach for students' musical lives in the future.

- Songs and maqams of Turkish music are not appropriate for children and hence, this kind of songs should not be part of the music education.

- Songs of less complex maqam which are appropriate for the level of children in terms of their lyrics and musical structure can be included in music education. Songs that cannot be performed by children, on the other hand, should just be listened so that children can acquire Turkish music culture.

- Appropriate pieces of Turkish music should be taught to children only through listening.

- In conveying Turkish music to students, temperament system should be employed.
} 
One composer (C5) indicated that Turkish music should be included in music education, as he believed that keeping it outside the scope of music education was not a realistic approach for students' musical lives in the future. Some composers $(\mathrm{C} 1, \mathrm{C} 2, \mathrm{C} 4)$ stated that, also to some extent confirming the previous opinion, songs of less complex maqam which were appropriate for the level of children in terms of their lyrics and musical structure could be included in music education. Respondents also thought that songs which were too complicated for children to perform should be taught to children only through listening.

Some composers (C4, C6, C7) did not regard songs and maqam structures of Turkish music appropriate for children, and therefore indicated these songs should not be included in music education. Even more, one of them (C7) was of the opinion that appropriate pieces of Turkish music should be taught to children only through listening. In parallel with the opinions of composers supporting the afore-mentioned statements due to the complexity of the maqam system, another composer (C3) suggested that temperament system should be employed to teach Turkish music to students.

Although composers' opinions were diverse, the overall tendency was to prefer teaching the pieces that were appropriate for children in terms of verbal and musical features only through listening activities.

\subsubsection{Popular Music}

Composers were asked to evaluate whether songs released particularly in popular children's songs competitions and in similar organizations could be used for the purposes of music education. Besides, they were requested to evaluate the fact that songs from such organizations were not used in music education although they appealed to children (See Table 9).

Table 9. Composers' opinions concerning the usability of songs of popular style in music education

\begin{tabular}{|c|c|c|}
\hline $\begin{array}{l}\text { Opinions on the } \\
\text { present situation }\end{array}$ & - & There is a gap in the repertoire that stem from the lack of songs of popular style. \\
\hline $\begin{array}{l}\text { Opinions concerning } \\
\text { the use of these songs } \\
\text { in music education }\end{array}$ & $\begin{array}{l}- \\
-\end{array}$ & $\begin{array}{l}\text { Children's songs released in popular children's songs competitions are usually composed for professional } \\
\text { children's choirs and therefore it can be hard to use them in music education. } \\
\text { The only objective of popular children's songs competitions might be to enhance the current repertoire. } \\
\text { The fact that popular songs are not included in music course books might depend on the songs, book writers } \\
\text { or teachers. }\end{array}$ \\
\hline $\begin{array}{l}\text { Recommendations on } \\
\text { the issue }\end{array}$ & $\begin{array}{l}- \\
-\end{array}$ & $\begin{array}{l}\text { Notes and records of popular songs should be released. } \\
\text { This kind of organizations should not be designed in the form of competitions but in the form of routine } \\
\text { events to enhance the repertoire. }\end{array}$ \\
\hline
\end{tabular}

Composers $(\mathrm{C} 4, \mathrm{C} 6)$ who believed that popular culture and its components permeated every section of our lives and it was not possible for us to avoid popular culture argued that popular music types and educational music pieces with popular features should be included in music education. Composers underlined the importance of some aspects for a composer to succeed in the area of educational music. These are composition self-development and keeping up with the current developments as well as being a good listener and knowledgeable about all types of music. Among the composers, only one respondent (C7) reacted differently to the issue. This composer defended the idea that educational music should not be confused with recreational music and therefore, only songs with popular components for some very specific purposes should be part of education.

Composers $(\mathrm{C} 1, \mathrm{C} 4, \mathrm{C} 5, \mathrm{C} 6, \mathrm{C} 7)$ indicated that children's songs released in TRT's popular children's songs competitions or in similar organizations appealed more to and were usually composed for professional children's choirs. Therefore, in such cases, composers tended to behave in a more flexible manner when composing songs and accordingly, they could broaden the vocal range or for example, could make piano accompaniment to the song harder. Composers also said that children in professional choirs received education for years, and therefore these songs would be hard for school choirs to sing; they also explained that absence of these songs from school books might be explained by this fact.

The fact that popular songs were not included in music course books might depend on the lack of knowledge by the side of book writers or teachers, according to some composers $(\mathrm{C} 1, \mathrm{C} 7)$ or it might be associated with the fact that authorities did not like these songs. In spite of this, children were willing to sing and actually happily sang songs from popular song competitions, according to some composers $(\mathrm{C} 4, \mathrm{C} 6)$ who noted that there was a gap in the repertoire that stemmed from the lack of songs of popular style. 
Composers $(\mathrm{C} 3, \mathrm{C} 5)$ stated that this kind of organizations should not be limited to competitions but they should be routine events supported by institutions and the media to enhance the popular songs repertoire. It was also indicated that through notifications delivered by different means; particularly music teachers and other parties in the area would be asked to share their compositions. They argued that after these songs were reviewed once again by experts, an annual repertoire including the best pieces from among those songs would be created.

In the light of the composers' opinions on the issue, it can be understood that songs of this type appeal more to professional choirs; however, there is a need for songs composed for educational purposes which are appropriate for the general level of difficulty of music education.

\subsubsection{Essential Features of a Good Composition}

Composers' opinions on the essential features that create an educational music song with good musical quality were asked (See Table 10).

Table 10. Composers' opinions on the essential features of a good composition

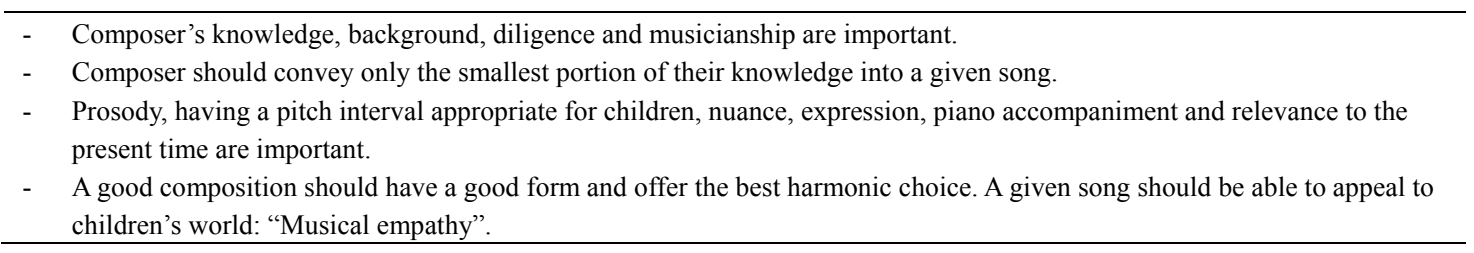

According to some composers $(\mathrm{C} 4, \mathrm{C} 7)$, a composer's musicianship and musical background were among the most important factors ensuring good quality in songs. Composers who claimed that if a composer was not a good musician, the result was an insipid music argued that diligence was of importance in the process of composition. Respondents (C4, C6, C7) who suggested that a composer should be selfish and convey only the smallest portion of their knowledge into a given song emphasized the necessity for composers to convey their message in plain, simple and catchy words. They also emphasized the importance of a simple and catchy melody and lyrics that could be easily memorized.

Three composers (C1, C2, C4) listed prosody, having a pitch interval appropriate for children, nuance, and components related to expression as important factors that ensured the quality of songs. They also expected lyrics to be, in terms of prosody, according to child philosophy and with the roundabout language children use and emphasized the necessity of piano accompaniment to songs, keeping up with the time and appealing to children in this regard.

Composers who said there might be many harmonic options for a song, yet choosing the best one was important and who identified harmonic richness as a significant factor $(\mathrm{C} 4, \mathrm{C} 7)$ were of the opinion that melodic structure and form should be good enough to be processed and to create polyphony. Besides, they argued that it was futile to work on a song which did not have a good melody and that songs like that would not be long-lasting.

One composer (C4) who claimed that listeners constituted the primary aspect to be taken into consideration when composing defined this as "musical empathy" and emphasized that it was important to think about the target audience when composing. This composer believed that songs composed for children should appeal to children's world.

\subsection{Educational Music Composing}

Data from this section on opinions and evaluation concerning educational music composing were coded in four sub-headings, namely aspects to be taken into account during the process of composition, essential skills and knowledge in addition to the ability to compose, types of music preferred in compositions, composing as a profession.

\subsubsection{The Process of Composing}

Composers were asked to evaluate the aspects to be taken into account when composing children's songs such as age group, grade levels, children's development levels, levels of readiness for learning, appropriateness for children's cognitive and emotional states, language development levels. Responses of the composers revealed the existence of differences in composers' approaches to and methods of composition (See Table 11). 
Table 11. Composers' opinions on the aspects to be taken into consideration in the process of composition

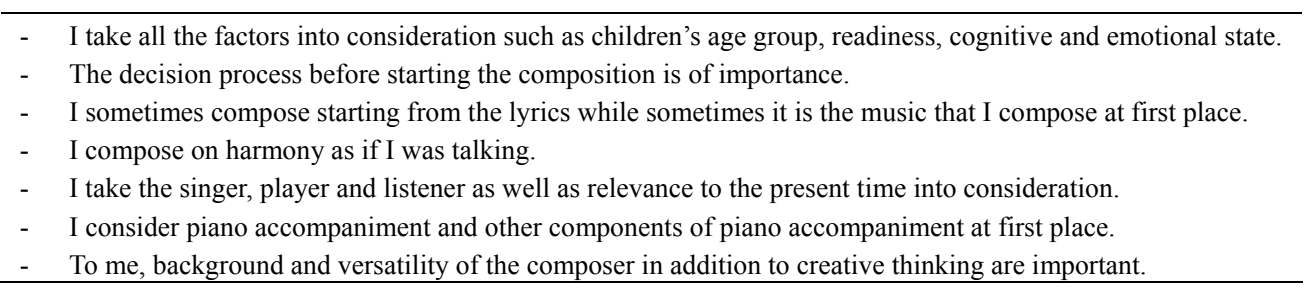

Composers $(\mathrm{C} 3, \mathrm{C} 6, \mathrm{C} 7)$ indicated that they paid attention to age group, grade levels, children's development levels, readiness for learning, appropriateness of subjects for children's emotional and cognitive state and language development. For example, one composer (C3) had composed two distinct songs for different grade levels about "traffic lights" which differed in all aspects ranging from the plot to the words, from range to rhythmic structure. This composer believed that this was what they were expected to do.

Another composer (C7) stated that he considered all components of a given song such as age group of the audience and in relation to this factor; lyrics, vocal range, and atmosphere etc. of the song before starting to compose it. This composer also believed that this was the normal and acceptable thing to do. Contrary to this composer's statement, another respondent (C5) admitted not making any decisions before the composition process and indicated that modal or tonal structure, and the range of a song would emerge by itself and piano accompaniment or other polyphonic features like two-voice or four-voice polyphony would be integrated into the song later on, if required.

One composer $(\mathrm{C} 2)$ was in favor of composing over lyrics instead of writing lyrics over a given piece of music as it was difficult in terms of prosody. Nevertheless, the composer said he sometimes tried to write lyrics for a given piece of music and in such cases, he kept a middle way and made some small amendments both on the music and the lyrics. This composer who usually set his own lyrics to music was of the opinion that lyrics and music should be handled together throughout the composition process. Another composer (C4) expressed that instead of setting lyrics to music or setting music to lyrics, he placed words on the harmony as if talking and in this way, the likelihood of prosodic impairment would be eliminated. The composer suggested that in this way it was easier to spot the melody within the words and to complete all compositions in shorter times.

One of the composers (C4) indicated that in the composition process, he gave consideration to singers and players as well as all the audience a given piece was going to reach and called it "musical empathy". Besides, he expected all composers to produce not up to their own taste but up to the taste of their audience. This composer also indicated that relevance to the present time should be another concern when composing. In other words, both the necessities and the present time should be given due consideration. Furthermore, according to the same composer, piano accompaniment was a significant complementary element for a song and that there were some criteria to be taken into consideration in piano accompaniment. The composer who stated that he took such components as an intro preparing the listeners to the song and the lyrics; parts with a piano solo as well as cadences indicated that he regarded the piano as an orchestra when composing piano accompaniment. This composer who treated the left hand of the piano as contrabass and brass instrument while considering the right hand as strings argued that it was necessary to reflect on all aspects of a song before the composition process.

Another composer (C7), on the other hand, suggested that he adopted a versatile way of thinking and a good background was what underlay this way of thinking. This composer who believed that the more knowledgeable a person was, the more versatile they could think stated that creative thinking and inventiveness were also of great importance. He added that it was necessary to be open to new methods if a chosen method failed to create a good composition.

In view of these data, it is clear that there are many different approaches to the process of composition. Therefore, considering this fact, it is possible to say that each composer follows their own personal approach in the composition process.

\subsubsection{Essential Skills and Knowledge in addition to the Ability to Compose}

Composers' opinions regarding the essential skills and knowledge for the practice in addition to the ability to compose were asked (See Table 12). 
Table 12. Composers' opinions regarding the essential skills and knowledge for the practice in addition to the ability to compose

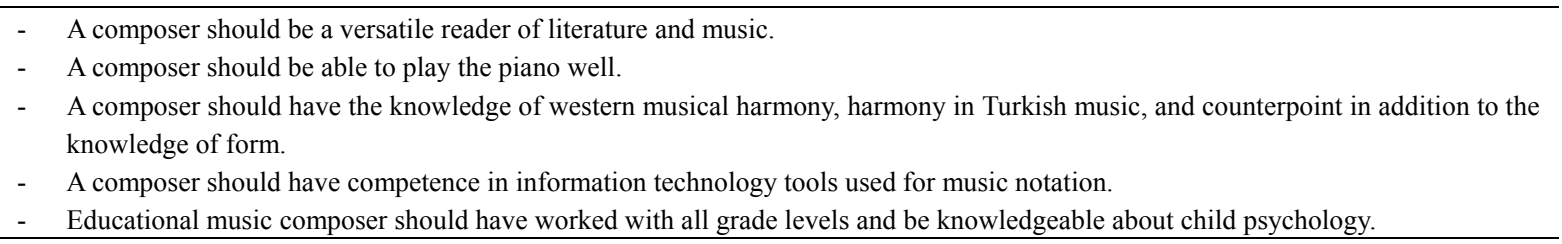

Composers $(\mathrm{C} 2, \mathrm{C} 3, \mathrm{C} 5, \mathrm{C} 7)$ emphasized the necessity for a composer to be a versatile reader and to read both musical and literary texts. They suggested that prospective composers should review the relevant literature thoroughly and be knowledgeable about it. They also underlined the significance of analyzing opinions and musical ideas properly as they believed it would be harder to forget something that was analyzed. Composers stated that the quality of compositions depended on a good background knowledge and a composer should have a good poetic taste and understand children well. Composers also said that composers should read texts on piano pieces, etudes and solfege so as to develop themselves in the area of music and that they needed a good musical hearing ability to achieve this.

Two composers $(\mathrm{C} 4, \mathrm{C} 5)$ argued that a good composer should be able to play the piano and that a certain level of piano knowledge was a must for composing.

Some respondents (C2, C4, C5, C7) claimed that a composer should have knowledge of harmony and a prospective composer should have the knowledge of both western musical harmony and harmony of modern Turkish music which contains some traditional timbres as well. They also referred to the knowledge of counterpoint and knowledge of form in addition to the knowledge of harmony. Apart from these, prospective composers were expected to have knowledge of form in order to be able create songs with a sound structure. For these purposes, prospective composers were recommended to analyze the works in the area.

One of the respondent composers (C4) pointed out the fact that a composer should have competence in information technology tools that facilitate educational music composing. The composer who regarded information technologies as the greatest aid for a composer stated that programs such as notation programs or orchestration programs facilitated the job of a composer.

Another composer (C6) had a different point of view saying a composer should have worked with all grade levels. One respondent (C4), on the other hand, supported this opinion by suggesting that, it wasn't possible to produce good compositions unless one knew children well and that one needed to be knowledgeable about child psychology to produce good compositions.

As can be understood from all these opinions of composers, a composer should be well-qualified in the area of music and be competent in the area of pedagogical approaches and child psychology.

\subsubsection{Preferred Music Types/Styles}

Composers were asked what types of music they benefited from when composing educational music songs and their responses are given in Table 13.

Table 13. Composers' opinions on music types preferred in compositions



Two of the respondents $(\mathrm{C} 4, \mathrm{C} 6)$ indicated that they composed children's music in all types, without distinction and added that different types of music were welcomed by children if these songs achieved to appeal them. Composers who were against such a distinction stated children liked songs of various types. A composer (C4) who was in favor of trying/utilizing different types reported that he composed in types that were adopted and liked by children and in this regard, a composer should work on these types and have a wider portfolio. A composer (C7) with a contrary point of view refrained from composing in popular style. This composer preferred tonal and modal music and did not prefer composing songs of "recreational music" type. According to their responses, composers $\mathrm{C} 1$ and $\mathrm{C} 4$, benefited from folk and art music in addition to modal music. 
In conclusion, composers said that when composing they utilized from elements of popular music, folk music and Turkish art music in addition to tonal and modal music. Composers who believed the most important thing was to compose for children and who argued that if this was kept in mind during the process of composition, children would love all types of music suggested that a composer should try new styles and have a wide portfolio.

\subsubsection{Composing as a Profession}

Composers' opinions regarding composing as a profession were explored and for this purpose, they were asked what they thought about music teachers' engagement in the practice of composing songs to be used in classroom settings. Besides, their responses to the question "Should educational music composition be practiced only by composers?" were asked (See Table 13).

Table 14. Composers' opinions regarding composing as a profession

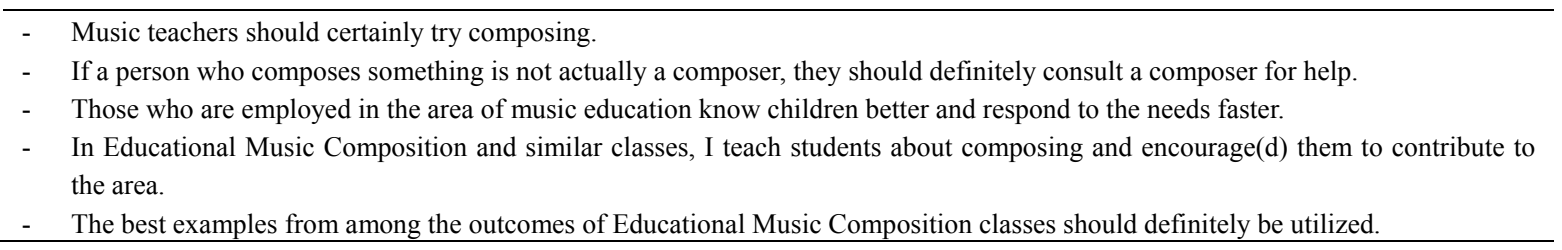

All composers $(\mathrm{C} 1, \mathrm{C} 2, \mathrm{C} 3, \mathrm{C} 4, \mathrm{C} 5, \mathrm{C} 6, \mathrm{C} 7)$ were of the opinion that composing songs for educational music was a serious job and they held that particularly music teachers should give it a try and develop themselves with regard to this area. They believed only in this way would good examples survive. One of the composers (C4) remarked that someone who was interested in the subject and was willing to work in the area should definitely have a mentor/teacher during this time and that if a person who wanted to compose something was not actually a composer, they should definitely consult a composer for help.

Compositions by those who were in the area of music education could appeal to children and were loved by children, in the words of two respondents $(\mathrm{C} 1, \mathrm{C} 5)$ who suggested there should not be any limitations regarding the person that composed a given piece. Some respondent composers believed that anyone who could create a song could compose and children loved the songs particularly by those who were experts in the area of educational music instead of songs by composers who produced compositions of large music forms. Other composers who argued that those employed in the area of music education could respond to needs faster indicated there were some universal examples like Bela Bartok (1881-1945) and Zoltan Kodaly (1882-1965) who produced compositions of large music forms while also composing educational music pieces. Another composer (C6) stated it wasn't right to expect great composers to work in the area of educational music as composers of educational music were expected to know children's lives and be part of this practice. They also suggested that this job required one to spend extra time to succeed. Furthermore, one composer (C6) who indicated there was a course called Educational Music Composition in bachelor programs of music education claimed that music teachers who didn't/couldn't compose songs for their students were not acceptable. In Educational Music Composition course, best examples from among educational music compositions should be analyzed according to one respondent $(\mathrm{C} 2)$ who thought compositions produced in these classes should be assessed, released, used, spread and their use should be encouraged. Composers C2, C4, C5, C6 and C7 said they encouraged their students to contribute to the area while composer $\mathrm{C} 4$ explained that he had the opportunity to work together with his teachers when he was a student and even to compete against them in competitions held in the following times adding he offered the same opportunity to his students as well. Two respondents (C5, C7) commented that apart from the Educational Music Composition course, in Musical Hearing, Reading \& Writing course and even in postgraduate degree courses, they assessed their students' compositions and promoted their students' engagement in the area. Finally, they indicated that they organized activities through which they promoted students in the area of composition to think and engage in hands-on-practice.

\section{Discussion, Conclusion and Suggestions}

The concept of educational music which attracts attention with the number of terms that exists in the literature to refer to it was adopted as the primary term in the present study due to the fact that it is an inclusive term in the area. It was revealed that different terms are used to refer to the concept while the term "educational music" is by far the most common one among composers. Composers stated that the subject concept could be used to indicate both verbal and non-verbal music and that it could be employed at different levels (educational stages, grade 
levels etc.) and in different environments (official education institutions, non-formal education institutions etc.). They also said that educational music was used as a teaching material in music education. Another noteworthy point is that some composers combined the term with the word "Turkish" (e.g., Turkish educational music, Turkish school music). Composers put particular emphasis on the importance of traditional and folk music examples as well as on modern educational music pieces inspired by folk music and culture; and hence it is believed that their sensitivity about the subject influenced their preferences regarding the term choice. It was found out that some composers preferred the terms "repertoire" and "children's music" while their term choices were seen to depend largely on their understanding of and approaches to the phenomenon of educational music. In this regard, the study proved that the situation mentioned by Aksu (2010) concerning the different uses of the term was in no way different from the perspective of composers.

Composers who handled the repertoire on the basis of age groups indicated that there was a sufficient number of songs for elementary \& middle education; however, they were of the opinion that the repertoire was inadequate for preschool and high school age groups. These opinions of composers confirm the findings of previous studies which argued that the repertoire of preschool songs was insufficient (Gül, 2012; Mohan, 2008). Composers who suggested that in previous years competitions were held to enhance the repertoire and thanks to these competitions, several songs were included in the repertoire in a very short time were of the opinion that, as it was also suggested by Gül (2012) and Özeren (2006), this job should be assumed by some institutions and if the current books and CDs would be released, the repertoire would be used more efficiently.

Composers pointed out the prosodic errors in the current songs. They added that, in spite of the errors, those songs were still in use in music education as they were incorporated into the language. In their study, Çavuşoğlu (2006) and Kalaycioğlu (2009) analyzed songs in music course books and concluded there were several songs with prosodic errors. Similarly, in the present study composers were of the opinion that the harmony between lyrics and music was an inseparable part of educational music pieces. Composers stated that giving due attention to the melody in the lyrics and integrating the lyrics into the music in a conversational style were necessary to compose songs without prosodic errors and to create harmony between lyrics and music.

Particularly one composer who suggested that several songs did not have piano accompaniment argued that songs remained incomplete without piano accompaniment. This composer added that the harmony of a song was the complementary element of a song and was what made a song beautiful; therefore, songs should be composed in a way that they could be accompanied by the piano. He also stated that a good composer and a good music teacher should absolutely be good at playing the piano. Apart from the matter of composing songs with piano accompaniment, several studies have identified problems in music teachers' accompaniment playing skills and have proposed some models for piano or guitar accompaniment of the current educational music pieces (Kalkanoğlu, 2007; Kutluk, 1996; Özkeleş, 2011; Parıldar, 2006; Yungul, 2008). In conclusion, depending on the findings from the present and previous studies, it is seen that accompaniment is regarded as an important issue for educational music not only by composers and music teachers but also by researchers in the area.

Composers underlined that all types of music without distinction should be included in music education and the portfolio of songs should be wide. They explained that the scope of the music taught to children should be wide and the most important thing was good and quality music which was composed for children or was appropriate for them. Composers thought that teaching the maqam system of Turkish music was not appropriate for children's level and instead of teaching the system to children; children could listen to the good examples or sing the songs that had lyrics appropriate for them. Composers who believed that popular culture and its components permeated every section of our lives and it was not possible for us to avoid popular culture argued that popular music types and educational music pieces with popular features should be included in music education. Composers underlined the importance of self-development and keeping up with the current developments as well as being a good listener and knowledgeable about all types of music in order to compose works of educational music. Some composers reacted differently to the issue by stating that educational music should not be confused with recreational music and therefore, only songs with popular components for some very specific purposes should be part of education. In this regard, it is clear that there wasn't agreement among composers regarding this issue.

Composers stated that songs of popular category which were composed for popular children's song competitions and which played an important role in the expansion of the repertoire appealed to children. In other words, they claimed that children were willing to sing these songs. They said that one of the reasons for the absence of these songs from course books was their level of difficulty. Although they recognized the considerable contribution to the repertoire provided by those songs as pieces composed for professional children's choirs, composers said that it could be hard to use them in music classes at schools. According to some composers, the fact that popular 
songs were not included in music education might result from the fact that book writers or teachers did not know them. Composers argued that children were willing to sing and actually happily sang songs from popular song competitions and noted once again that there was a gap in the repertoire that stemmed from the lack of songs of popular style. According to respondents, composers should work towards closing this gap and the number of competitions and similar organizations held for this purpose should be increased. In a similar vein, in his study, Selamet (2009) argued that songs competing in such organizations could be released as books and CDs which could ensure that those songs were more visible in the area of music education.

Composers suggested that songs of educational music should not necessarily remain only as course materials, but rather they should be of a style that could penetrate in children's daily lives. They also pointed out that songs to be used in music education should be composed with diligence and that composing songs for children required one to get into children's world. Composers expressed that songs which appealed to children should help children divert to the right path in their future lives and offer guidance to them. They also stated that if not only musical features but also the afore-mentioned aspects were taken into consideration during the process of composition, songs were welcomed by children. Composers indicated that songs with these features could be used both in education and in children's daily lives.

According to composers, in order for songs to be of good musical quality; first of all a musician and a qualified composer who constantly improved himself/herself and secondly, easy and catchy melodies and lyrics, prosody, melodic sequence, harmonic structure and form components were important. Songs composed with due consideration to those aspects could be of good musical quality. According to composers, musical quality of a song depended on the musicianship and background of a composer.

Some composers who said that they paid attention to the age of the target audience and vocal range of the song in their own composition process listed harmonic structure, piano accompaniment and particularly prosodic components as aspects that required attention. Some composers set lyrics to music; some set music to lyrics while some adopted both styles depending on the situation. It was revealed that when composing, one composer wrote words to match the harmony he had. They were also of the opinion that compositions should be relevant to the necessities of the time. For example, Satır (2009) found out that many songs in music course books of the 1st, 2nd and 3rd grades of elementary school were not appropriate for the conceptual-cognitive development levels of children and were also not up to the standards of modern children's literature. Similar to the respondent composers, he also argued that conceptual-cognitive and language levels of children in addition to musical structure and lyrics should be given due consideration during the process of composition.

As to the composers' opinions on the types of music to be included in music education, they pointed out that they composed songs with popular components and components of folk music and traditional Turkish art music in addition to tonal and modal scales. Composers who frequently underlined the necessity to move with the times emphasized the importance of being open-minded and trying new methods. In doing so, what should be taken into consideration is, as they said previously, to compose songs that are appropriate for children and would be loved by children.

Composers emphasized the necessity for a composer, particularly an educational music composer to be qualified not only in the area of music but also in the area of literature. They suggested that composers were expected not only to read music well but also to be a good reader of literary texts. They stated that composers should review and analyze the songs in the repertoire extensively. Composers argued that a good composer should be able to play the piano well and have a good knowledge of harmony, counterpoint and form. Respondent composers pointed out the fact that a composer should have competence in information technology tools that change and develop every day. They replied that using programs for notation programs or orchestration programs etc. facilitated composing and contributed to this process. According to respondent composers, a music composer should know children well and be knowledgeable about child psychology. Respondents also stated that having worked with all grade levels as a teacher would provide considerable contribution to composition skills.

All composers held that particularly music teachers should give it a try to compose songs and that they should definitely have a mentor who would support their composition process and would help them during this time. Composers thought that it was of importance for music teachers to compose as they would respond to composition needs in shorter times. They believed, in this way, good compositions would be loved and performed by children while bad examples would not survive in the repertoire and in the end would disappear. Composers who were at the same time academics commented that apart from the educational music composition courses, they promoted students to the area of composition and endeavored to help them develop their composition skills through practices in undergraduate and postgraduate degree courses. 
Conclusions of the research were explained below and the following recommendations can be made in the light of these conclusions:

A commission of educational music composers should select the songs which are loved by children and of high musical quality from among the songs in the educational music repertoire and alternative sources like "Classical Educational Music" or "National Song Repertoire" should be built. These songs can be released by the Ministry of Culture or Ministry of National Education and in this way, quality songs will be collected in one resource and it will be easier to hand them down to future generations. These resources should be prepared in accordance with a set of criteria including age groups, educational stages and educational purposes so that it can be easier for individuals to access what they need. Furthermore, if a CD record of these songs is prepared by professional children's choirs and this CD is copied and distributed, it will be even easier to access this repertoire.

It is seen that the repertoire is not sufficient for preschool and high school age groups. Events and competitions can be organized by ministries, universities and private institutions in order to encourage educational music composers to produce songs particularly for these age groups. In this way, the area of educational music will gain some dynamism and the repertoire will be enhanced by the new songs. Furthermore, if class hours for music are increased for all preschool, elementary school, middle school and high school grades and if preschool and elementary \& middle education music classes are offered by music teachers and if music is offered as a compulsory course instead of an elective at high school grades, the quality and effect of music classes will grow. Accordingly, songs in the repertoire and song activities will have a wider coverage in music education.

Not only composers but also music teachers and prospective music teachers should be encouraged to compose songs for educational music. Competitions in addition to festivals, workshops and other activities should be organized by institutions (MNE, Ministry of Culture, universities, media companies etc.) only for music teachers and prospective music teachers to encourage them to contribute to the educational music repertoire.

In Educational Music Composition course at departments of music education at faculties of education, educational music composing should be analyzed from different perspectives. Apart from reaching compositions of good musical quality, students should be taught and encouraged to make practice concerning composing songs for educational music in different types and/or approaches. All these practices should be carried out by all professional music institutions (conservatories, schools of fine arts etc.) with equal care. Some initiatives are also required to include educational music pieces composed by students during their class hours in the subject repertoire. For these purposes, compositions should be performed at schools and they should be songs that are teachable at schools during "Teaching Practice" classes. Besides, students should be able to offer feedback concerning those songs. Quality pieces produced in Educational Music Composition classes should be selected by the lecturer of the course and in this way, alternative resources should be created.

Individuals who are engaged in educational music composing process should take the popular music aspect into consideration which has a place in children's lives and from which children cannot avoid due to the flow of their lives. Other television channels in addition to TRT should organize events, competitions and television programs to promote the composition of children's songs which involve popular elements and appeal to children. In this way, both composers' and children's interest in the events can be boosted thanks to private television channels, which have the potential to reach a wider audience. Thanks to these regular events organized under specific themes, it will be possible to add more than one song into the repertoire and to encourage composers to work in the area.

In addition to the present study which handles composers' opinions on Turkish educational music, a further study needs to be conducted in the area to explore the opinions of music teachers, who constitute a larger group and have the duty to apply this music, as well as those of students, who are the target audience of this educational music. Such a study will also complement the present study and make it possible to compare composers' opinions to music teachers' and students' opinions.

In addition to the above, for ensuring the inclusion of educational music pieces into daily life and their implementation as well as for ensuring the intense engagement of children/young people in the art of music; city, town and school choirs should be established. These choirs which can be established by municipalities, universities, NGOs etc. will enliven the subject place in terms of educational music and the art of music. For this purpose, if the current/future boards of art at the subject organizations deal with the issue and approach the issue in a sensitive way, this will be beneficial for the future studies in the area as well. 


\section{Acknowledgments}

This study was summarized from the first author's master thesis which called "The Evaluation of Turkish School Music In Accordance With the Opinions of Composers".

\section{References}

Akbulut, F. (2001). Gitar Eşlikli Okul Şarkılarının Müzik Eğitimindeki Önemi [The Importance of School Songs with Guitar Accompaniment]. İstanbul: İstanbul University Institute of Social Sciences.

Aksu, C. (2010). Türkiye'de Eğitim Müziği [Educational Music in Turkey] (1st ed.). İstanbul: Bemol Music Publisihing.

Aktaş, S. (2008). İlköğretim II. Kademe Okul Şarkılarının Öğrencilere Uygunluğunun İncelenmesi [Examination of Suitability of Secondary School's Songs for Children]. İstanbul: Marmara University Institute of Educational Sciences.

Arapgirlioğlu, H. (2003). Türk Okul Şarkılarının Teknoloji Destekli Çok Seslendirilmesine İlişkin Yaklaşımlar [Approaches to Technologic Phplyphonization of Turkish School Songs]. Ankara: Gazi University Institute of Educational Sciences.

Bağçeci, S. E. (1996). Dörtlü Armoni Sistemi ile Modal Tarzdaki Ĕgitim Müziği Şarkılarının Çokseslendirilmesi Üzerine Bir Çalışma [A Study on Polyphony of Educational Songs in Modal Style by means of Fourth Harmony System] . Konya: Selçuk University Institute of Sciences.

Bilgin, A. S. (2009). İlköğretim Öğrencilerinin Okul Şarkılarına Yönelik Görüşleri [Opinions of Elementary School Students on School Songs]. Bolu: Abant İzzet Baysal University Institute of Social Sciences.

Çavuşoğlu, E. (2006). Türkiye'deki İlköğretim Okullarının II. Kademesinde Müzik Eğitiminde Kullanılan Okul Şarkilarının Prozodi Yönünden İncelenmesi [Determine how eligible prosody principles which are taught during music classess at primary schools (II. level) in Turkey]. Ankara: Gazi University Institute of Educational Sciences.

Çepni, S. (2010). Araştırma ve Proje Çalışmalarına Giriş [Introduction to Research and Project Studies] (5th ed.). Trabzon: Celepler Publishing.

Dinç, A. (2011). Kazım Karabekir'e Ait Çocuk Şarkılarının Eğitim Müziği Açısından Değerlendirilmesi [Evaluation of Children's Songs Composed by Kazım Karabekir in terms of Educational Music]. Erzurum: Atatürk University Institute of Educational Sciences.

Görsev, A. (2006). Abant İzzet Baysal Üniversitesi Müzik Ĕgitimi Anabilim Dalı Son Sinıf Öğrencilerinin Piyano Eğitimi, Müzik Teorisi ve İşitme Eğitimi ve Eşlik (Korrepetisyon) Dersleri ile Okul Şarkalarına Doğaçlama Eşlik Becerileri Arasindaki Ilisşkiler [The Relationship between the Courses Entitled Piano Education, Music Theory and Hearing Education and Accompaniment and the Skills of Improvised Accompaniment to the School Songs of the Last Year Students of Abant İzet Baysal University Department]. Bolu: Abant İzzet Baysal University Institute of Social Sciences.

Gül, G. (2012). Okul Öncesi Altı Yaş Çocukları İçin Oluşturulan Şarkı Dağarcı̆̆ının Müziksel Gelişsim Düzeylerine Etkisi [The Efficiency of the Song Repertoire on the Musical Development Level of Pre-School Children Aged Six Years Old]. Bursa: Uludağ University Institute of Educational Sciences.

Gül, G., \& Bozkaya, İ. (2010). Osman Zeki Üngör’ün “Çocuklara Teganni Dersleri” Kitabı Üzerine Bir Çalışma [A Work About Osman Zeki Üngör's Book Called "Çocuklara Teganni Dersleri (Singing Songs Lessons for Children)"]. UIudă̆ Üniversitesi Ĕgitim Fakültesi Dergisi, XXIII(1), 133-156.

Güler, L. (2009). Illköğretim II. Kademe (6. 7. ve 8. Sinıflar) Müzik Dersi Kitaplarında Türk Müziği Okul Şarkilarina Ayrlan Yer [The Place of School Songs of Turkish Music in Music Course-Books of Primary Schools at Secondary Level (6th, 7th, and 7th grades)]. İstanbul: Haliç University Institute of Social Sciences.

Halvaşi, B. (1999). Ulusal Şarkı Söyleme Geleneğinin Oluşturulmasından Türk Dili ve Fonetiğinin İncelenmesi [Examination of Turkish Language and Phonetics from the Creating of the National Song Tradition]. İstanbul: Marmara University Institute of Sciences.

Kalaycıoğlu, Ş. G. (2009). Türkiye'deki İlköğretim Okullarında Müzik Eğitiminde Kullanılan Okul Şarkılarının, Eğitim Müziği Besteleme Teknikleri Bakımindan Incelenmesi [The Analysis of Children Songs Used for Music Education in Primary Schools in Turkey on the basis of Composition Techniques of Education Music]. Malatya: İnönü University Institute of Social Sciences. 
Kalkanoğlu, B. (2007). Okul Şarkılarının Müzik Öğretmenlerinin Bilgi ve Beceri Düzeyine Göre Piyano ile Eşliklenmesine Yönelik Bir Eşlik Modeli Önerisi. Ankara: Gazi University Institute of Educational Sciences.

Kaptan, Z. (2001). Klasik Gitarın Türk Halk Müziği Kaynaklı Okul Şarkılarında Kullanımı [Using of Classical Guitar in Turkish School Songs Welding from Folk Music]. Ankara: Gazi University Institute of Sciences.

Koz, E. (2007). İlköğretim Íkinci Kademe'de Görev Yapan, Bireysel Çalgı Eğitimi ( Gitar ) Alanı Mezunu, Müzik Öğretmenlerinin Okul Şarkılarına Eşlik Etmede Karşılaştıkları Problemler ve Çözüm Önerileri [Problems and Suggestions for Accompaniment to MusicTeachers who Play the Guitar (as a major instrument) and Teach in Secondary Schools]. Konya: Selçuk University Institute of Social Sciences.

Kutluk, Ö. (1996). Okul Şarkılarına Piyano ile Eşlik Yapabilme Becerisinin Gelişstirilmesi Üzerine Bir Çalışma [A Study on Developing the Skills of Accompanying School Songs with Piano]. Konya: Selçuk University Institute of Sciences.

Mohan, H. (2008). Okul Öncesi Ĕgitiminde Belirli Günler ve Haftalara Yönelik Şarkı Dağarcı̆̆ı ile İlgili Öğretmen Görüsleri [Teachers' Opinion on Repertoire of Songs Aimed at Specific Days and Weeks for Pre-School Children]. Ankara: Gazi University Institute of Educational Sciences.

Nebi, G. (2005). Makedonya ve Türkiye İlköğretim Okulları 6, 7, ve 8. Sinıf Ders Kitaplarında Okutulan Müzik Ders Kitaplarındaki Eğitim Müziği Eserlerinin Karşılaş̧tırılmalı Incelenmesi [The Comparison Analysis of Educational Music Compositions that are consisted in the Music Education Books used in 6, 7 and 8. Grade at Primary Schools between Macedonia and Turkey]. Bolu: Abant İzzet Baysal University Institute of Social Sciences.

Özdemir, M. A. (1998). Türk Halk Müziği Sistematiği ve Ĕgitim Müziği Besteciliğinde Kullanılabilirliği [Systematic of Turkish Folk Music and Usability in Educational Music Composition]. İstanbul: Marmara University Institute of Sciences.

Özelma, Y. (2010). Illköğretim Müzik Derslerinde Çoksesli Şarkıların Yeri, Önemi ve Ĕ̆itim Müziği Çokseslendirme Yaklaşımları [The Role and Importance of Polyphonic Songs in Primary Music Lessons and Approaches for Polyphonic Educational Music]. Burdur: Mehmet Akif Ersoy University Institute of Social Sciences.

Özeren, A. (2001). İlköğretimde Konu Başllklarına Göre Bir Okul Şarklları Kitabı Denemesi [In Primary Education, A Trial Book about School Songs according to the Titles of the Subjects]. İstanbul: İstanbul Technical University Institute of Social Sciences.

Özeren, A. (2006). Çocuklar İçin Yaratılan Müzik Yapıtlarının Toplumsal Müzik Bilinci ve Dil Gelişimi Açısından Rolü ve Önemi [The Role and Importance of Music Created for Children in terms of Social Music Awareness and Language Development]. II. National Symposium on Children and Youth Literature. Ankara.

Özkeleş, S. (2011). Okul Şarkılarının Latin Müziği Stillerinin Ritmik Yapıları ile Eşiklenmesine Ilişkin Yaklaşlmlar [Approaches which are related to the Accompaniment of School Songs with the Rhythmic Structures of Latin Music Styles]. Malatya: İnönü University Institute of Educational Sciences.

Parıldar, G. (2006). Okul Şarkllarının Gitar Eşliklemelerinde Şematik Yöntem Kullanımı [Application of Schematic Method for Guitar Accompaniment of School Songs]. Ankara: Gazi University Institute of Educational Sciences.

Patton, M. Q. (2002). Qualitative research and evaluation methods ( $3^{\text {rd }}$ ed.). California: Sage Publications, Inc.

Sağer, T. (1998). Okul Müziği Çerçevesinde Geleneksel Türk Sanat Müziği Makam sistemi Üzerine Bir İnceleme [A Study on the Traditional Turkish Art Music Modesystem in the frame of Music for Schools]. Ankara: Gazi University Institute of Sciences.

Sağer, T. (2002). Cumhuriyetten Günümüze Okul Şarkllarl Üzerine Bir İnceleme [A Research on Songs from the Republic Today's]. Ankara: Gazi University Institute of Educational Sciences.

Sağer, T. (2004). Okul Şarkılarının Konuları Açısından Değerlendirilmesi [Evaluation of School Songs in Terms of Subjects]. 1924-2004 Musiki Muallim Mektebinden Günümüze Müzik Öğretmeni Yetiştirme Sempozyum Kitabı (pp. 231-250). Isparta: Süleyman Demirel University Publishing.

Sak, Ö. S. (1997). İlköğretim Okullarında Müzik Eğitimi ve Çocuk Şarkıları Üzerine Bir Araştırma [A Research about the Children Songs and the Music Education at Primary Schools]. Konya: Selçuk University Institute of Sciences. 
Satır, Ö. C. (2009). İlköğretim Sürecinde Çocuklara Seslenen Şarkıların Dil ve Anlatım Yönünden Değerlendirilmesi [Evaluation of Songs Addressing Children in terms of language and expression in Primary Education]. Uluslararası Araştırmalar Dergisi, 9(2), 387-394.

Selamet, S. (2009). TRT Popüler Çocuk Şarkılarının Okul Müzik Eğitiminde Kullanılması [The Use of TRT Popular Child Songs in the Music Education]. Ankara: Gazi University Institute of Educational Sciences.

Semiz, Z. (2010). Eğitim Müziğinde Bilgisayar Teknolojisinin Kullanımı ve Gitar Eşlikli Okul Şarkıları (CD) [The Use of Computer Technology in Music Education and School Guitar Songs]. Bolu: Abant İzzet Baysal University Institute of Social Sciences.

Sun, M. (1969). Türkiye'nin Kültür-Müzik-Tiyatro Sorunlarl [Culture-Music-Theater Problems in Turkey] (p. 2). Ankara: Ajans Türk Kültür Yayınları.

Tamer, Z. (2004). Ortaöğretim Okulları 9. Sinıf Müzik Programında Öğretilen Şarkı Dağarının Kullanılmasında Karşılaşılan Sorunlar ve Şarkı Dağarı Denemesi [Problems Met During the Use of the Repertoire Taught in the 9th Class Music Programme and Repertoire Trials]. İstanbul: Marmara University Institute of Educational Sciences.

Yağışan, N. (1995). Ortaöğretim Müzik Öğretimi İlke ve Amaçları ile Bazı Ĕ̆itim Müziği Kitaplarının Analizi [Principles and Objectives of Secondary Music Teaching and Analysis of Some Educational Music Books]. Konya: Selçuk University Institute of Sciences.

Yıldırım, A., \& Şimşek, H. (2011). Sosyal Bilimlerde Nitel Araştırma Yöntemleri [Qualitative Research Methods In The Social Sciences]. Ankara: Seçkin Publishing.

Yıldız, N. (2005). Çocuk Şarkıları Üzerine Bir İnceleme [A Study on Children's Songs]. Tiyatro Araştırmaları Dergisi, 20, 73-100.

Yılmaz, E. (2010). Okul Şarkılarının Klasik Gitar ile Eşliklendirilmesine Yönelik Öğretmen Görüşleri ve Okul Şarklları İ̧̧in Eşliklendirme Örnekleri [Teachers' Opinions about School Songs which were Accompanimented with Guitar and the Accompaniment Examples for School Songs]. Niğde: Niğde University Institute of Social Sciences.

Yungul, O. (2008). Okul Şarkllarının Gitar ile Eşliklenmesinde Örnek Bir Model [A Sample Model for Guitar Accompaniment of School Songs]. Ankara: Gazi University Institute of Educational Sciences.

\section{Copyrights}

Copyright for this article is retained by the author, with first publication rights granted to the journal.

This is an open-access article distributed under the terms and conditions of the Creative Commons Attribution license (http://creativecommons.org/licenses/by/4.0/). 